\title{
Epidemiological, clinical and diagnostic aspects of sheep conidiobolomycosis in Brazil
}

\author{
Aspectos epidemiológicos, clínicos e de diagnóstico da conidiobolomicose ovina no Brasil
}

\author{
Carla Weiblen ${ }^{\mathrm{I}}$ Daniela Isabel Brayer Pereira ${ }^{\mathrm{II}}$ Valéria Dutra ${ }^{\mathrm{II}}$

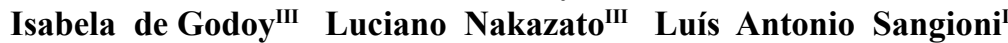 \\ Janio Morais Santurio ${ }^{I V}$ Sônia de Avila Botton ${ }^{I^{*}}$
}

\section{- REVIEW -}

\section{ABSTRACT}

Conidiobolomycosis is an emerging disease caused by fungi of the cosmopolitan genus Conidiobolus. Particular strains of Conidiobolus coronatus, Conidiobolus incongruus and Conidiobolus lamprauges, mainly from tropical or sub-tropical origin, cause the mycosis in humans and animals, domestic or wild. Lesions are usually granulomatous and necrotic in character, presenting two clinical forms: rhinofacial and nasopharyngeal. This review includes the main features of the disease in sheep, with an emphasis on the epidemiology, clinical aspects, and diagnosis of infections caused by Conidiobolus spp. in Brazil. In this country, the disease is endemic in the Northeast and Midwest, affecting predominantly woolless sheep breeds and occasioning death in the majority of the studied cases. The species responsible for infections of sheep are $\boldsymbol{C}$. coronatus and . lamprauges and the predominant clinical presentation is nasopharyngeal. These fungal infections are very important, since they compromise the health status of the sheep flock and cause serious economic losses to the sheep industry. Thus, research is needed to investigate faster tools for diagnosis and effective methods for the control and treatment of conidiobolomycosis.

Key words: Fungal infection, ovine, zygomycosis, Conidiobolus spp.

\section{RESUMO}

Conidiobolomicose é uma enfermidade emergente causada por fungos cosmopolitas do gênero Conidiobolus. Isolados de Conidiobolus coronatus, Conidiobolus incongruus e Conidiobolus lamprauges, principalmente de origem tropical e subtropical, afetam humanos, animais domésticos e silvestres.
As lesões da conidiobolomicose normalmente são de caráter granulomatoso e necrótico, apresentando-se sob duas formas clínicas: rinofacial e nasofaringea. O presente artigo tem como objetivo revisar as principais características da doença em ovinos, particularizando a epidemiologia, assim como os aspectos clínicos e o diagnóstico das infecções causadas por Conidiobolus spp. no Brasil. Neste País, a enfermidade é endêmica nas regiões nordeste e centro-oeste, afetando ovinos predominantemente de raças deslanadas, ocasionando a morte na grande maioria dos casos estudados. As espécies do fungo responsáveis pelas infecções em ovinos são $\boldsymbol{C}$. coronatus e $\boldsymbol{C}$. lamprauges e a forma clínica predominante é a nasofaríngea. Tais infecções fúngicas são muito importantes, uma vez que comprometem o status sanitário do rebanho ovino e acarretam sérios prejuizos econômicos à ovinocultura. Dessa forma, pesquisas são necessárias para investigar ferramentas rápidas de diagnóstico e métodos eficazes de controle e tratamento da conidiobolomicose.

Palavras-chave: micose, ovino, zigomicose, Conidiobolus spp.

\section{INTRODUCTION}

Conidiobolomycosis is considered an emerging disease caused by several species of fungi of the cosmopolitan genus Conidiobolus in phylum Entomophthoromycota. The latter in one of six major phylogenetic lineages recognised among the former phylum Zygomycota (GRIGANSKI et al., 2013). Pathogenic Conidiobolus species infects

IPrograma de Pós-graduação em Medicina Veterinária (PPGMV), Departamento de Medicina Veterinária Preventiva (DMVP), Centro de Ciências Rurais (CCR), Universidade Federal de Santa Maria (UFSM), Santa Maria, RS, Brasil.

IIDepartamento de Microbiologia e Parasitologia, Instituto de Biologia, Campus Universitário Capão do Leão, Universidade Federal de Pelotas (UFPEL), Pelotas, RS, Brasil.

IIILaboratório de Microbiologia Veterinária e Biologia Molecular, Universidade Federal de Mato Grosso (UFMT), Cuiabá, MT, Brasil.

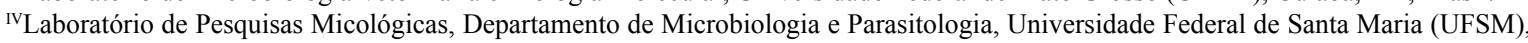

Av. Roraima, 1000, 97105-900, Santa Maria, RS, Brasil. E-mail: sabott20@gmail.com. *Corresponding author. 
human beings (TADANO et al., 2005;MICHAEL et al., 2009; KIMURA et al., 2011; BACHELET et al., 2014) as well as various species of domestic and wild animals (Table 1). The majority of Conidiobolus are non-pathogenic saprobes or opportunistic pathogens of arthropods and occur worldwide, but Conidiobolus coronatus, Conidiobolus incongruus and Conidiobolus lamprauges are the most frequent etiological agents of the conidiobolomycosis. Their pathogenic strains occur mainly in tropical and subtropical regions, in areas of high humidity, particularly in Africa (EL-SHABRAWI et al., 2014); however, cases have been reported worldwide (Table 1), including Brazil (Table 2).

Conidiobolomycosis is characterized by granulomatous and necrotic lesions and it shows two clinical manifestations: rhinofacial and nasopharyngeal infection (SILVA et al., 2007a,b; RIET-CORREA et al., 2008). In recent years, there is an increasing number of case reports of disease affecting woolless sheep flocks in Brazil, especially in the Northeast and Midwest regions (Table 2). This fact evidences that the epidemiological conditions in the country are favorable for proliferation and maintenance of the fungus in the environment.

Brazilian sheep industry is becoming increasingly widespread and it is characterized by two aspects of production, including meat and skin (mainly the Northeast region) and meat and wool (especially in the South region) (IBGE, 2002). The conidiobolomycosis in sheep flocks compromises the health status of the herd and causes economic losses to sheep breeding, since mortality and lethality rates

Table 1- Reported cases of conidiobolomycosis in animal species from outside Brazil.

\begin{tabular}{|c|c|c|c|c|c|c|}
\hline Species & $\begin{array}{l}\text { Number of } \\
\text { affected hosts }\end{array}$ & $\begin{array}{l}\text { Country/Year of disease } \\
\text { occurrence or reported }\end{array}$ & Organism & Site of infection & Outcome & Reference \\
\hline \multirow{4}{*}{ Dog } & 1 & United States/1994 & Conidiobolus spp. & Skin & $\mathrm{D}$ & 1 \\
\hline & 1 & United States/1996 & Conidiobolus spp. & Oral & $\mathrm{R}$ & 2 \\
\hline & 1 & United States/2006 & Conidiobolus spp. & Pulmonary & $\mathrm{R}$ & 3 \\
\hline & 1 & United States/2014 & C. incongruus & Pulmonary & $\mathrm{D}$ & 4 \\
\hline \multirow{2}{*}{ Deer } & 1 & Australia/1997 & C. incongruus & Disseminated & $\mathrm{D}$ & 5 \\
\hline & 1 & United States/2009 & C. incongruus & Disseminated & $\mathrm{D}$ & 6 \\
\hline \multirow{5}{*}{ Horse } & 1 & United States/1989 & C. lamprauges & Nasopharyngeal & $\mathrm{D}$ & 7 \\
\hline & 1 & United States/1996 & C. coronatus" & Nasopharyngeal & $\mathrm{D}$ & 8 \\
\hline & 1 & United States/2001 & C. coronatus & Granulomatous tracheitis & $\mathrm{R}$ & 9 \\
\hline & 1 & United States/2001 & C. coronatus & Nasopharyngeal & $\mathrm{R}$ & 10 \\
\hline & 2 & United States/2003 & C. coronatus & Nasopharyngeal & $\mathrm{R}$ & 11 \\
\hline \multirow{2}{*}{ Llama } & 1 & United States/1992 & C. coronatus & $\begin{array}{l}\text { Nodular dermatosis in } \\
\text { external nares/Respiratory }\end{array}$ & RI & 12 \\
\hline & 1 & United States/1994 & C. coronatus & $\begin{array}{l}\text { Granulomatous dermatitis } \\
\text { and nasal commitment }\end{array}$ & $\mathrm{D}$ & 13 \\
\hline $\begin{array}{l}\text { Non } \\
\text { human } \\
\text { primates }\end{array}$ & 1 & United States/1982 & Conidiobolus spp.* & Disseminated & $\mathrm{D}$ & 14 \\
\hline \multirow{3}{*}{ Sheep } & 700 & Australia/1992 & C. incongruus & Rhinofacial & $\mathrm{D}$ & 15 \\
\hline & $5 / 200$ & Australia/1992 & C. incongruus & $\begin{array}{l}\text { Rhinofacial } \quad(n=1) \quad \text { and } \\
\text { Rhinocerebral }(n=4)\end{array}$ & $\mathrm{D}$ & 16 \\
\hline & $1 / 60$ & Trinidad/2001 & Conidiobolus spp. & Rhinocerebral & $\mathrm{D}$ & 17 \\
\hline
\end{tabular}

${ }^{1}$ HILLIER et al. (1994), ${ }^{2}$ BAUER et al. (1997), ${ }^{3}$ HAWKINS et al. (2006), ${ }^{4}$ MACKEY et al. (2015), ${ }^{5}$ STEPHENS \& GIBSON (1997), ${ }^{6}$ MADSON et al. (2009), ${ }^{7}$ HUMBER et al. (1989), ${ }^{8}$ ZAMOS et al. (1996), ${ }^{9}$ STEIGER \& WILLIAMS (2000), ${ }^{10}$ ROBINSON et al. (2007). ${ }^{11}$ TAINTOR et al. (2004), ${ }^{12}$ MOLL et al. (1992), ${ }^{13}$ FRENCH \& ASHWORTH (1994), ${ }^{14}$ MIGAKI \& TOFT (1982), ${ }^{15}$ CARRIGAN et al. (1992), ${ }^{16}$ KETTERER et al. (1992), ${ }^{17}$ MORRIS et al. (2001). D=Died. R=Recovered. RI=Remaining infection. ${ }^{*}$ Case was not confirmed with culture. 
reach 100\% (SILVA et al., 2007a,b; RIET-CORREA et al., 2008, MENDONÇA et al., 2012; AGUIAR et al., 2014). These issues justify the concern about the occurrence of the disease in Brazilian sheep herds. Thus, this review describes the main epidemiological and clinical features, as well as the diagnostic methods relevant to conidiobolomycosis in sheep in Brazil.

Etiological agents

Conidiobolus genus belongs to the kingdom Fungi, Phylum Entomophthoramycota and
Entomophthorales order (GRIGANSKI et al., 2013). Morphologically, Conidiobolus spp. have hyaline, coenocytic hyphae or shorter hyphal bodies, although septa may be more infrequentthanl the older parts of the mycelium (CHAYAKULKEEREE et al., 2006). Rounded dilations are often seen at the ends of hyphae and these enlargements have been also described in case of conidiobolomycosis (KETTERER et al., 1992; SILVA et al., 2007b, BOABAID et al., 2008). These fungi are characterized by producing asexual spores, which are relatively large globose

Table 2- Epidemiological and clinical aspects of ovine conidiobolomycosis outbreaks reported in Brazil, $1979-2014$.

\begin{tabular}{|c|c|c|c|c|c|c|c|c|}
\hline $\begin{array}{l}\text { State/year of } \\
\text { disease occurrence }\end{array}$ & Clinical form & $\begin{array}{l}\text { Affected } \\
\text { sheep (n) }\end{array}$ & $\begin{array}{l}\text { Total of } \\
\text { sheep }(n)\end{array}$ & Lethality \% & Breed & $\begin{array}{l}\text { Climatic } \\
\text { condition of } \\
\text { the region } \\
\text { (month of } \\
\text { the year) }^{*}\end{array}$ & $\begin{array}{l}\text { Conidiobolus } \\
\text { species }\end{array}$ & Reference \\
\hline MG/1979 & $\mathrm{NI}$ & 3 & $\mathrm{NI}$ & $\mathrm{NI}$ & $\mathrm{SI} / \mathrm{MN}$ & $\mathrm{NI}$ & Conidiobolus spp. & 1 \\
\hline $\mathrm{PB} / 2001$ & Rhinofacial & 5 & 80 & 100 & SI & Feb-May & Conidiobolus spp. & 2 \\
\hline \multirow[b]{4}{*}{$\mathrm{PI} / 2002 / 2003 / 2004$} & \multirow[b]{4}{*}{ Nasopharyngeal } & 157 (2002) & $6380(2002)$ & \multirow[t]{4}{*}{100} & \multirow[t]{4}{*}{$\mathrm{SI} / \mathrm{MN}$} & \multirow[t]{4}{*}{ Apr-Jun } & \multirow[t]{4}{*}{ C. coronatus } & \multirow[t]{4}{*}{3} \\
\hline & & $152(2003)$ & $6115(2003)$ & & & & & \\
\hline & & $212(2004)$ & $6086(2004)$ & & & & & \\
\hline & & $\begin{array}{l}173.66 \\
\text { (average of } \\
\text { number of } \\
\text { cases) }\end{array}$ & $\begin{array}{l}6194 \text { (mean } \\
\text { of exposed } \\
\text { animals) }\end{array}$ & & & & & \\
\hline $\mathrm{PB} / 2004$ & Nasopharyngeal & 8 & 140 & 100 & $\mathrm{SI} / \mathrm{Ca}$ & Jan-May & Conidiobolus spp. & 2 \\
\hline $\mathrm{SC} / 2006$ & Nasopharyngeal & 6 & 75 & 100 & SI & Dec-May $^{* *}$ & C. lamprauges & 4 \\
\hline MT/2006-2012 & Rhinofacial & 2 & NI & 100 & SI & Jan-Jan & C. lamprauges & 5 \\
\hline MT/2007 & Nasopharyngeal & 12 & 40 & 100 & SI & Jan-Jun $^{* *}$ & Conidiobolus spp. & 6 \\
\hline $\mathrm{RS} / 2007$ & Nasopharyngeal & 1 & 30 & 100 & $\mathrm{Tx}$ & Jan-Apr & Conidiobolus spp. & 7 \\
\hline $\mathrm{PE} / 2009$ & Nasopharyngeal & 5 & 29 & 100 & NI & Apr-May $^{* *}$ & Conidiobolus spp. & 8 \\
\hline $\mathrm{PB} / \mathrm{RN} / 2009-2012$ & Rhinofacial & $\begin{array}{l}299 \\
17^{\#}\end{array}$ & 1333 & 100 & $\mathrm{SI} / \mathrm{CB}$ & $\begin{array}{l}\text { Mar/2009 - } \\
\text { Dez/2012 }\end{array}$ & Conidiobolus spp. & 9 \\
\hline MT/NI & Nasopharyngeal & 9 & NI & NI & SI & $\mathrm{NI}$ & C. lamprauges & 10 \\
\hline
\end{tabular}

Brazilian States: MG=Minas Gerais; MT=Mato Grosso; PB=Paraíba; PE=Pernambuco; PI=Piauí; RN=Rio Grande do Norte; RS=Rio Grande do Sul; SC=Santa Catarina. NI=no informed. SI=Santa Inês. MN=Morada Nova. Ca=Cariri.Tx=Texel. $\mathrm{CB}=\mathrm{Cross}$ breed. ${ }^{*} \mathrm{All}$ of those regions reported high pluviometric precipitation and high humidity periods; including the presence of considerable amounts of

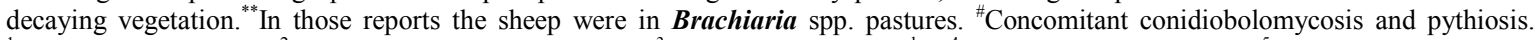
${ }^{1}$ SILVA et al. (2010), ${ }^{2}$ RIET-CORREA et al. (2008), ${ }^{3}$ SILVA et al. (2007 $\left.{ }^{\mathrm{a}, \mathrm{b}}\right)$, ${ }^{4}$ FURLAN et al., (2010), ${ }^{5}$ UBIALI et al. (2013), ${ }^{6}$ BOABAID et al. (2008), ${ }^{7}$ PEDROSO et al. (2009), ${ }^{8}$ MENDONÇA et al. (2012), ${ }^{9}$ AGUIAR et. al. (2014), ${ }^{10}$ DE PAULA et al. (2010). 
conidia borne singly on conidiophores and forcibly discharged. In general, these conidia have basal buds (papillae) with rounded and prominent shape (SIDRIM \& ROCHA et al., 2008). However, sexual spores (zygospores) in cultures are different among the three known mammalian pathogenic Conidiobolus species. C. lamprauges has smaller zygospore than $\boldsymbol{C}$. incongruus and has often only a single large homogeneous globule inside the mature conidia. Conversely, $\boldsymbol{C}$. incongruus has various small globules inside it's mature conidia. In $\boldsymbol{C}$. coronatus zygospore are absent (VILELA et al., 2010), but sometimes characteristic villose resistant spores are formed by conidia.

Species of Conidiobolus pathogens have the ability to assimilate carbohydrates and grows well at $37^{\circ} \mathrm{C}$ (CHAYAKULKEEREE et al., 2006). SILVA et al. (2012) also reported that $C$. lamprauges when exposed to temperature of $37^{\circ} \mathrm{C}$ overexpresses enolase, suggesting that this enzyme has potential involvement in host-pathogen relationship and virulence of this fungus. GODOY et al. (2014) suggest that $\boldsymbol{C}$. lamprauges produces a range of proteins that are related to thermoregulation triggered by the high temperature of the host.

\section{Epidemiology}

Conidiobolomycosis cases were described in tropical regions such as: Africa, South America, Central America, and Asia (CHAYAKULKEEREE et al., 2006; EL-SHABRAWI et al., 2014). In Brazil, the disease is considered endemic in flocks of the Northeast and Midwest regions, being reported in ovine in the states of Piauí (SILVA et al., 2007a,b), Paraíba (RIET-CORREA et al., 2008), Pernambuco (MENDONÇA et al., 2012), and Mato Grosso (BOABAID et al., 2008; DE PAULA et al., 2010). Sporadic cases were also reported in ovine in the Southern region, in the states of Santa Catarina (FURLAN et al., 2010) and Rio Grande do Sul (PEDROSO et al., 2009). In Brazil the occurrence of conidiobolomycosis has ranged from 0.1 to $17.2 \%$ and the lethality rate always was $100 \%$ (SILVA et al., 2007a, b; MENDONÇA et al., 2012).

Table 2 lists the ovine conidiobolomycosis outbreaks reported in Brazil, including the years 1979 to 2014. Epidemiological conditions that determined the occurrence of the disease in sheep in the country were generally associated with periods of high rates of rainfall, temperatures between $19^{\circ} \mathrm{C}$ and $36^{\circ} \mathrm{C}$, high relative humidity and increased decaying plant matter on the environment (SILVA et al., 2007a; BOABAID et al., 2008; PEDROSO et al., 2009; FURLAN et al., 2010; MENDONÇA et al., 2012). Such conditions favor the proliferation of the fungus and, consequently, increase environmental contamination and predispose susceptible animals to inhalation of conidia. In three outbreaks the animals were in Brachiaria spp. pastures (BOABAID et al., 2008; FURLAN et al., 2010; MENDONÇA et al., 2012). This type of vegetation might increase the fungus proliferation in the environment, since this vegetation produces considerable amount of organic matter being an ideal substrate for fungal growth. In all reports, the disease was observed in the period from December to June, coinciding with the hottest and humid periods in all regions where there were reports of sheep conidiobolomycosis (Table 2).

The main mode of infection involves inhalation, ingestion and dermal exposure to conidia of these fungi (DE PAULA et al., 2010). The most common route of infection is by inhalation of conidia present in the grazing (HUMBER et al., 1989). These authors observed that the conidia might be ejected to a height of more than two centimeters from the soil. Thus, these conidia might reach the nasal mucosa. Another route of contamination might be due to injury caused by sharp plants contaminated with conidia (KETTERER et al., 1992). SILVA et al. (2007a) suggested that the prevalence of the disease in sheep might be related to the grazing habits of these animals favoring the inhalation of conidia.

\section{Clinical manifestations}

Ovine conidiobolomycosis is clinically manifested by the following forms: rhinofacial and nasopharyngeal (rhinopharyngeal) infection. The clinical course for both clinical forms varies from 1 to 5 weeks. The rhinofacial infection commonly affects the nasal vestibule, the mucocutaneous union of the nose, the upper lip, the skin of the muzzle, the proximal region of the face and the hard palate (SILVA et al., 2008a, b; RIET-CORREA et al., 2008). However, the animals affected by the nasopharyngeal form usually show apathy, progressive weight loss, serous to mucosa and/or bleeding nasal secretion, as well as breathing difficulty and fever. The involvement of the ethmoid region, nasal turbinates, paranasal sinuses, soft palate, orbit, pharyngeal muscles, and lymph nodes also have been described in this clinical form. The lesion may progress to the eye socket determining unilateral exophthalmia and several ocular injuries (RIET-CORREA et al., 2008; SILVA et al., 2007a,b).

Table 2 shows that the predominant clinical presentation in sheep conidiobolomycosis outbreaks 
reported in Brazil was nasopharyngeal. It was also observed that in the described outbreaks, both clinical forms of the disease did not occur concurrently, except in a single outbreak (UBIALI et al., 2013). In these outbreaks, the main species identified were $\boldsymbol{C}$. lamprauges and $\boldsymbol{C}$. coronatus. According to UBIALI et al. (2013) infections caused by $\boldsymbol{C}$. lamprauges were mainly related to nasopharyngeal form. Nevertheless, the same authors reported $\boldsymbol{C}$. lamprauges in both clinical forms of sheep in Mato Grosso state.

The disease caused by $\boldsymbol{C}$. incongruus is rare and has not been described in sheep in Brazil. However, this agent has medical importance (ELSHABRAWI et al., 2014) and it was reported in ovine in Australia (KETTERER et al., 1992; CARRIGAN et al., 1992) and in dogs in United States of America (MACKEY et al., 2015).

\section{Diagnosis}

The definitive diagnosis of ovine conidiobolomycosis includes clinical and pathological findings associated with the mycological diagnosis involving the isolation and identification of the etiological agent.

\section{Mycological diagnosis}

The fungal growth on Sabouraud Dextrose Agar (SDA) or Potato Dextrose Agar (PDA) is usually evident after 5 days at $37^{\circ} \mathrm{C}$ and produces colonies that are wrinkled, white or pigmented (DE PAULA et al., 2010). On SDA, the colonies at the beginning are flat, glabrous, waxy and cream color (DE PAULA et al., 2010; VILELA et al., 2010), subsequently they became wrinkled and yellowed. On PDA, the colonies are thin, flat and smooth, with pleats in the center (VILELA et al., 2010). Microscopically, Conidiobolus spp. present large conidia (diameter 25 to $45 \mu \mathrm{m}$ ), pyriform to spherical, born singly on unbranched conidiophores and expelled violently from these structures. In general, these conidia have basal buds (papillae) with rounded and prominent shape (SIDRIM \& ROCHA et al., 2008).

Pathological diagnosis: macroscopic and microscopic aspects

Macroscopic aspects

In nasopharyngeal form of sheep conidiobolomycosis, macroscopically there is the proliferation of whitish or yellowish tissue, irregular, friable of granular consistency located in ethmoid and nasal septum. Frequently, the eye socket may be affected, causing craniofacial asymmetry and exophthalmia. In addition, an obstruction of the nasal meatus with retention of mucopurulent exudate in the frontal sinuses was observed. An irregular nodular proliferation obstructing the choanae, as well as infiltration of the cribriform plate and eye socket causing the protrusion of the eyeball were also reported. Lesions spread to the brain, lungs, lymph nodes, kidneys, heart, and gallbladder were noticed (SILVA et al., 2007b; RIET-CORREA et al., 2008; BOABAID et al., 2008; FURLAN et al., 2010; MENDONÇA et al., 2012).

RIET-CORREA et al. (2008) reported the rhinofacial infection of sheep conidiobolomycosis in the Brazilian state of Paraíba. In this form, gross lesions were characterized by the presence of dark brown ulcerated areas in the nasal mucosa, extending from mucocutaneous region into the nasal vestibule. The mucosa of the hard palate also showed a large ulcerated area, involving the gums and premolars. The cut surface of the nostrils and hard palate showed a brown or reddish spongy tissue with friable consistency. In this clinical form, lesions were not observed in other organs (e.g. the brain, lungs and lymph nodes) but they were reported in the nasopharyngeal form.

\section{Microscopic aspects}

On histopathological examination, the lesions of conidiobolomycosis sheep stained with hematoxylin-eosin were characterized by multifocal granulomas with a central necrosis area and eosinophilic granular appearance (RIET-CORREA et al., 2008). Inside the granulomas there were negatively stained structures representing the fungal hyphae surrounded by abundant Splendore-Hoeppli material. The necrotic areas were often surrounded by inflammatory cells, particularly eosinophils, neutrophils, mononuclear cells, multinucleated giant cells, and epithelioid macrophages (SILVA et al., 2007b; BOABAID et al., 2008; RIET-CORREA et al., 2008). Estructures as Hypha could be observed within giant cells (SILVA et al., 2007b; MENDONÇA et al., 2012). With Gomori's methenamine silver stain of these lesions, numerous thick hyphae were observed. These structures were rarely septate, irregular in shape, with black contoured wall, sometimes with bulbous dilatation in the extremities (SILVA et al., 2007b; BOABAID et al., 2008; RIET-CORREA et al., 2008; FURLAN et al., 2010; MENDONÇA et al., 2012).

According to DE PAULA et al. (2010) the pathological aspects of conidiobolomycosis have been similar to other zygomycoses described, as well as pythiosis. All of these illnesses are characterized by the formation of granulomatous lesions and are 
difficult to treat. Consequently, it is necessary to conduct a careful differential diagnosis.

Serological and molecular diagnosis

$$
\text { UBIALI et al. (2013) utilized }
$$

immunohistochemistry with polyclonal serum to perform a differential diagnosis of granulomatous rhinitis in sheep. Previously, SILVA et al. (2010) used this technique to confirm the fungal etiology of conidiobolomycosis in ovine. Several authors have suggested the use of molecular biology assays to search DNA sequences of conserved genes in fungal samples, including polymerase chain reaction (PCR) and DNA sequencing of intergenic regions (internal transcribed spacer, ITS) and ribosomal DNA units (18S, 5.8S and 28S rDNA) (DE PAULA et al., 2010; BOTTON et al., 2011; SILVEIRA et al., 2013). DE PAULA et al. (2010) and SILVEIRA et al. (2013) proposed the use of PCR to amplify the $18 \mathrm{~S}$ rDNA region of pathogenic Conidiobolus. SILVEIRA et al. (2013) confirmed the difficulty in identifying this microorganism in fungal culture, which was possible only in $26.6 \%$ from clinical samples. These authors also highlighted the importance of the use of molecular techniques for the definitive diagnosis of ovine conidiobolomycosis.

\section{Differential diagnosis}

For a long time, conidiobolomycosis in ovine was erroneously diagnosed as enzootic ethmoid tumor (SILVA et al., 2007a). However, the enzootic nasal tumor also known as enzootic nasal adenocarcinoma is a contagious chronic disease of goats and sheep, with viral etiology (retrovirus). Macroscopically, it is presented as unilateral or bilateral masses, pale, friable, located in the region of the ethmoid turbine and adjacent areas. Microscopically, the lesions may present features of adenomas to adenocarcinomas, usually classified as low malignancy adenocarcinoma (PORTELA et al., 2010).

Another relevant disease to be considered as differential diagnosis of conidiobolomycosis is pythiosis. In sheep, pathogenic Conidiobolus and Pythium insidiosum may be associated with rhinofacial rhinitis and nasopharyngeal infection; however, it is observed that conidiobolomycosis lesions in general are associated with the nasopharynx and these lesions have an aspect of a yellow or white firm mass (AGUIAR et al., 2014). In contrast, pythiosis is associated with the rhinofacial region with production of necrotic and friable tissues (SANTURIO et al., 2008; UBIALI et al., 2013). Additionally, significant morphological differences are observed among the lesions caused by both microorganisms. Conidiobolomycosis shows an evident pattern of multifocal granulomatous lesion with wide hyphae (diameter of 7-30 $\mu \mathrm{m}$ ) surrounded by an abundant amount of Splendori-Hoeppli material. Again, in contrast, in pythiosis there is a marked caseous necrosis and thinner hyphae when compared to hyphae of pathogenic Conidiobolus, and surrounded by discrete Splendori-Hoeppli reaction (RIET-CORREA et al., 2008; PORTELLA et al., 2010; UBIALI et al., 2013).

\section{Therapeutic approaches}

The late diagnosis and the lack of a standard protocol of treatment for this fungal infection are factors that may contribute to the high lethality of Conidiobolus spp. infection (SILVA et al., 2007a). So far, no drug or chemical has been completely effective in the treatment of conidiobolomycosis (RIET-CORREA et al., 2008; KIMURA et al., 2011; SILVA et al., 2012). VALLE et al. (2001) proposed a combination of triazoles, itraconazole and fluconazole, in the treatment of rhinomycosis by $\boldsymbol{C}$. coronatus in humans; however, there are no reports of any effective treatment in sheep. HAWKINS et al. (2006) described a successful treatment with itraconazole employed in a dog with fungal pneumonia caused by a pathogenic Conidiobolus. Later, TONDOLO et al. (2013) performed in vitro susceptibility to the assay against isolates of $\boldsymbol{C}$. lamprauges from sheep using amphotericin B, azoles, echinocandins, and terbinafine. These authors concluded that only terbinafine was active against this fungus and the microorganism demonstrated resistance or reduced susceptibility to the other antifungal drugs evaluated.

\section{CONCLUSION}

Ovine conidiobolomycosis is an endemic disease in Brazil, especially in the Northeast and Midwest regions, affecting predominantly the woolless sheep. The occurrence of the disease is related to climate conditions of these regions. $\boldsymbol{C}$. coronatus and $\boldsymbol{C}$. lamprauges are responsible for the sheep infections in Brazil.

Further information about the epidemiology of conidiobolomycosis, as well as the virulence factors and pathogenicity of the agent, is required in order to develop effective control and prevention measures of this important disease that affects sheep flocks in Brazil.

\section{ACKNOWLEDGEMENTS}

The authors thank for the financial support from Conselho Nacional de Desenvolvimento Científico e Tecnológico (CNPq) (Process 473162/2013-0). Additional acknowledgedments 
to Fundação de Amparo à Pesquisa do Estado do Rio Grande do Sul (FAPERGS) and Coordenação de Aperfeiçoamento de Pessoal de Nível Superior (CAPES).

\section{REFERENCES}

AGUIAR, G.M.N. et al. Epidemiological aspects of conidiobolomycosis in sheep in the Northeastern Brazilian semiarid region. Ciência Rural, v.44, n.12, p.2210-2216, 2014. Available from: $<$ http://dx.doi.org/10.1590/0103-8478cr20131472>. Accessed: June 30, 2015. doi: 10.1590/0103-8478cr20131472.

BACHELET, J.T. et al. Infection à Conidiobolus coronatus révélée par une tumeur de la face. Revue de Stomatologie, de Chirurgie Maxillo-faciale et de Chirurgie Orale, v.115, n.2, p.114-117, 2014. Available from: <http://www.sciencedirect.com/science/ article/pii/S2213653313002759>. Accessed: May 20, 2015. doi: 10.1016/j.revsto.2013.12.003.

BAUER, R.W. et al. Oral conidiobolomycosis in a dog. Veterinary Dermatology, v.8, p.115-120, 1997.

BOABAID, F. M. et al. Conidiobolomycosis in sheep in the state of Mato Grosso, Brazil. Pesquisa Veterinária Brasileira v.28, n.1, p.777-781, 2008. Available from: <http://www.scielo. $\mathrm{br} /$ scielo.php?pid $=\mathrm{S} 0100-736 \mathrm{X} 2008000100012 \& \mathrm{script}=\mathrm{sci}$ arttext>. Accessed: May 20, 2015. doi: 10.1590/S0100736X2008000100012.

BOTTON, S. A. et al. Identification of Pythium insidiosum by nested PCR in cutaneous lesions of Brazilian horses and rabbits. Current Microbiology, v. 62, n. 4, p. 1225-1229, 2011. Available from: $<$ http://link.springer.com/article/10.1007\%2Fs00284-010-9781-4>. Accessed: May 20, 2015. doi: 10.1007/s00284-010-9781-4.

CARRIGAN, M. J. et al. Ovine nasal zygomycosis caused by Conidiobolus incongruus. Australian Veterinary Journal, v. 69 , n.10, p. 237-240, 1992. Available from: <http://www.ncbi.nlm.nih. gov/pubmed/1445069>. Accessed: May 20, 2015.

CHAYAKULKEEREE, M. et al. Zygomycosis: the re-emerging fungal infection. European Journal of Clinical Microbiology \& Infectious Diseases, v. 25, n.4, p.215-229, 2006. Available from: $<$ http://link.springer.com/article/10.1007/s10096-006-0107-1>. Accessed: May 20, 2015

DE PAULA, D. A. J. et al. Molecular characterization of ovine zygomycosis in central western Brazil. Journal of Veterinary Diagnostic Investigation, v. 22, n. 2, p. 274-277, 2010. Available from: <http://vdi. sagepub.com/content/22/2/274.long >. Accessed: May 20, 2015.

EL-SHABRAWI, M. H. F. et al. Entomophthoromycosis: a challenging emerging disease. Mycoses, v. 57, Suppl. 3, p.132-137, 2014. Available from: $<$ http://onlinelibrary.wiley.com/doi/10.1111/ myc.12248/epdf $>$. Accessed: Sept. 18, 2015.

FRENCH, R. A.; ASHWORTH, C.D. Zygomycosis caused by Conidiobolus coronatus in a llama (Lama glama). Veterinary Pathology, v.31, n.1, p.120-122. 1994. Available from: <http:// Conidiobolomicosevet.sagepub.com/content/31/1/120.1ong $>$. Accessed: May 20, 2015.

FURLAN, F. H. et al. Conidiobolomycosis caused by Conidiobolus lamprauges in sheep in the state of Santa Catarina, Brazil. Pesquisa Veterinária Brasileira, v.30, n.7, p.529-532,2010
Available from: <http://www.scielo.br/scielo.php?pid=S0100736X2010000700003\&script $=$ sci_arttext $>$. Accessed: May 20, 2015. doi: 10.1590/S0100-736X2010000700003.

GODOY, I. et al. Differential expression of protein of the fungus Conidiobolus lamprauges cultivated at different temperatures. Ciencia Rural, v. 44, n. 3, p. 473-478, 2014. Available from $<$ http://www.scielo.br/scielo.php?script=sci_arttext\&pid=S010384782014000300014\&lng=en\&nrm=iso $>$. Accessed: Sept. 15, 2015. doi: 10.1590/S0103-84782014000300014.

GRYGANSKI, A. P. et al. Phylogenetic lineages in Entomophthoromycota. Persoonia,v.30, n. 1, p.94-105,2013.Available from: <http://www.ncbi.nlm.nih.gov/pmc/articles/PMC3734969/>. Accessed: Sept. 15, 2015. doi: 10.3767/003158513X666330.

HAWKINS, E. C. et al. Treatment of Conidiobolussp. pneumonia with itraconazole in a dog receiving immunosuppressive therapy. Journal of Veterinary Internal Medicine, v.20, n.6, p.14791482, 2006. Available from: <http://onlinelibrary.wiley.com/ doi/10.1111/j.1939-1676.2006.tb00769.x/abstract>. Accessed: May 20, 2015. doi: 10.1111/j.1939-1676.2006.tb00769.x.

HILLIER, A. et al. Canine subcutaneous zygomycosis caused by Conidiobolus sp.: a case report and review of conidiobolus infections in other species.Veterinary Dermatology, v.5, p. $205-$ $213,1994$.

HUMBER, R. A. et al. Equine zygomycosis caused by Conidiobolus lamprauges. Journal of Clinical Microbiology, v. 27, n.3, p. 573-576, 1989. Available from: <http://www.ncbi.nlm. nih.gov/pmc/articles/PMC267365/>. Accessed: May 20, 2015. doi:10.1080/01913120500482013

IBGE (INSTITUTO BRASILEIRO DE GEOGRAFIA E ESTATÍSTICA). Available from: <http://www.ibge.gov.br/home/ estatistica/economia/agropecuaria/censoagro/default.shtm $>$. Accessed: May 20, 2015.

KETTERER, P.J. et al. Rhinocerebral and nasal zygomycosis in sheep caused by Conidiobolus incongruus. Australian Veterinary Journal, v. 69. n. 4, p. 85-87, 1992.

KIMURA, M. et al. Disseminated human conidiobolomycosis due to Conidiobolus lamprauges. Journal of Clinical Microbiology, v.49, n.2, p.752-756, 2011. Available from: <http://jcm.asm.org/ content/49/2/752.full>. Accessed: May 20, 2015. doi: 10.1128/ JCM.01484-10

MACKEY, P.E. et al. Disseminated Conidiobolus incongruus in a dog: a case report and literature review. Medical Mycology Case Reports, v. 8, p. 24-28, 2015. Available from: <http:// www.elsevier.com/locate/mmcr>. Accessed: Jun. 04, 2015. doi:10.1016/j.mmcr.2015.02.005.

MADSON, D. et al. Systemic Conidiobolus incongruus infection and hypertrophic osteopathy in a white-tailed deer (Odocoileus virginianus). Journal of Veterinary Diagnostic Investigation. v. 21, p.167-170, 2009. Available from: <http://vdi.sagepub.com/ content/21/1/167.full.pdf + html $>$. Accessed: Sept. 18, 2015.

MENDONÇA, F.S. et al.Conidiobolomycosis in sheep in the state of Pernambuco. Revista Brasileira de Medicina Veterinária, v. 34, n. 3, p. 241-246, 2012. Available from: <http://www.rbmv.com. br/pdf_artigos/07-11-2012_10-42RBMV\%20015.pdf>. Accessed: May 20, 2015. 
MICHAEL, R.C. et al. Unusual presentation of entomophthoromycosis. Indian Journal of Medical Microbiology, v. 27, n. 2, p.156-158, 2009. Available from: <http:// www.ijmm.org/article. asp? issn $=02550857$; year $=2009 ;$ volume $=27$ ;issue $=2 ;$ spage $=156$; epage $=158 ;$ aulast $=$ Michael $>$. Accessed: May 20, 2015. doi: 10.4103/0255-0857.49432.

MIGAKI, G. et al. Disseminated entomophthoromycosis in a mandrill (Mandrillus sphinx). Veterinary Pathology, v. 19, n 5, p. 551-554, 1982. Available from: <http://vet.sagepub.com/ content/19/5/551>. Accessed: Sept. 22, 2015.

MOLL, H.D. et al. Entomophthoramycosis conidiobolae in a llama. Journal of the American Veterinary Medical Association,v. 200, n.7, p. 969-970, 1992.

MORRIS, M. et al. Rhinocerebral zygomycosis in a sheep. Canadian Veterinary Journal. v. 42, n.3, p. 227-228, 2001. Available from: $<$ http://www.ncbi.nlm.nih.gov/pmc/articles/PMC1476464/pdf/ canvetj00003-0069.pdf>. Accessed: May 20, 2015.

PEDROSO, P.M.O. et al. Rhinopharyngeal mycotic rhinitis in a Texel sheep in Rio Grande do Sul. Acta Scientiae Veterinariae, v. 37, n. 2, p. 181-185, 2009. Available from: <http://www.ufrgs.br/ actavet/37-2/art829.pdf>. Accessed: May 20, 2015.

PORTELA, R.A. et al. Diseases of the nasal cavity of ruminants in Brazil. Pesquisa Veterinária Brasileira, v. 30, n. 10, p. $844-854,2010$. Available from: <http:// www.scielo.br/scielo.php? script $=$ sci_arttext\&pid $=$ S 0100 736X2010001000007>. Accessed: May 20, 2015. doi:10.1590/ S0100-736X2010001000007.

RIET-CORREA, F. et al. Outbreaks of rhinofacial and rhinopharyngeal zygomycosis in sheep in Paraíba, northeastern Brazil.Pesquisa Veterinária Brasileira, v. 28, n. 1, p. 29-35, 2008. Available from: <http://www.scielo.br/scielo.php?script=sci arttext\&pid $=$ S0100-736X2008000100005>. Accessed: May 20, 2015. doi: 10.1590/S0100-736X2008000100005.

ROBINSON, C.S. et al. Treatment of a mare for Conidiobolus coronatus infection. Equine Veterinary Education, v.19, n.8, p.396-403, 2007. Available from: <http://onlinelibrary.wiley.com/ doi/10.2746/095777307X220452/pdf>. Accessed: Sept. 21, 2015. doi: $10.2746 / 095777307 \mathrm{X} 220452$.

SIDRIM, J.J.C.; ROCHA, M.F.G. Micologia médica a luz de autores contemporâneos. Rio de Janeiro. Guanabara Koogan. 408p, 2008.

SILVA, S.M.M.S. Epidemiology and symptoms of conidiobolomycosis in sheep in the State of Piauí, Brazil. Pesquisa Veterinária Brasileira, v.27, n.4, p.184-190,2007a. Available from: $<$ http://www.scielo.br/scielo.php?script $=$ sci arttext\&pid $=$ S0100-736X2007000400010>. Accessed: May 20, 2015. doi: 10.1590/S0100-736X2007000400010.

SILVA, S.M.M.S. et al. Conidiobolomycosis in sheep in Brazil. Veterinary Pathology, v. 44, n. 3, p. 314-319, 2007b. Available from: $\quad<$ http://vet.sagepub.com/cgi/pmidlookup?view=long\&pm id=17491072 $>$. Accessed: May 20, 2015.

SILVA, J.A.G. et al. Thermoregulated genes differentially expressed in Conidiobolus lamprauges. Ciência Rural, v.42, n. 9, p. 1610-1613, 2012. Available from: <http://www.scielo. br/scielo.php?pid $=$ S0103-84782012000900015\&script $=$ sci arttext $>$. Accessed: May 20, 2015. doi: 10.1590/S010384782012005000064 .

SILVEIRA, M. M. et al. Development and application of polymerase chain reaction test for detection of Conidiobolus lamprauges. Pesquisa Veterinária Brasileira, v.33, n.12, p.1448-1452, 2013. Available from: <http://www.scielo.br/ scielo.php?pid $=$ S0100-736X2013001200009\& $\mathrm{script}=\mathrm{sci}$ arttext $>$. Accessed: May 20, 2015. doi: 10.1590/S0100736X2013001200009.

STEIGER, R. R.; WILLIAMS, M.A. Granulomatous tracheitis caused by Conidiobolus coronatus in a horse. Journal of Veterinary Internal Medicine, v. 14, p. 311-314, 2000. Available from: $<$ http://onlinelibrary.wiley.com/doi/10.1111/j.1939-1676.2000. tb01172.x/epdf>. Accessed: Sept. 22, 2015.

STEPHENS, C.; GIBSON, J. Disseminated zygomycosis caused by Conidiobolus incongruus in a deer. Australian Veterinary Journal. v. 75, n. 5, p. 358-359, 1997.

TAINTOR, J. et al. Treatment of conidiobolomycosis with fluconazole in two pregnant mares. Journal of Veterinary Internal Medicine, v. 18, n. 1, p. 363-364, 2004. Available from: $<$ http://onlinelibrary.wiley.com/doi/10.1111/j.19391676.2004. tb02560.x/abstract; jsessionid=2FE7EFC53EF204FC571F9E70A CD30968.f04t01>. Accessed: Sept. 15, 2015. doi: 10.1111/j.19391676.2004.tb02560.x.

TADANO, T. et al. Entomoftoromicose (zigomicose) causada por Conidiobolus coronatus em Mato Grosso (Brasil): relato de caso.Revista da Sociedade Brasileira de Medicina Tropical, v. 38, n. 2, p. 188-190, 2005. Available from: $<$ http://www.scielo.br/scielo.php?script $=$ sci arttext\&pid $=$ S0037-86822005000200013 $>$. Accessed: May 20, 2015. doi: $10.1590 / \mathrm{S} 0037-86822005000200013$.

TONDOLO, J.S. et al. In vitro susceptibility of Conidiobolus lamprauges recovered from sheep to antifungal agents. Veterinary Microbiology, v.166, n.3-4, p.690-693,2013. Available from: $<$ http:// www.sciencedirect.com/science/article/pii/S0378113513003866>. Accessed: May 20, 2015. doi: 10.1016/j.vetmic.2013.07.024.

UBIALI, D.G. et al. Pathology of nasal infection caused by Conidiobolus lamprauges and Pythium insidiosum in sheep. Journal of Comparative Pathology, v.149, n.2-3, p.137-145, 2013. Available from: <http://www.sciencedirect.com/science/ article/pii/S0021997512004355>. Accessed: May 20, 2015. doi: 10.1016/j.jcpa.2012.12.002.

VALLE, A. C. et al. Entomophthoramycosis by Conidiobolus coronatus. Revista do Instituto de Medicina Tropical de São Paulo, v. 43, n. 4, p. 233-236, 2001.

VILELA, R. et al. Morphologic and phylogenetic characterization of Conidiobolus lamprauges recovered from infected sheep. Journal of Clinical Microbiology, v. 48, n. 2, p. 427-432, 2010. Available from: <http://www.ncbi.nlm.nih.gov/pmc/articles/ PMC2815615/pdf/1589-09.pdf>. Accessed: May 20, 2015. doi: 10.1128/JCM.01589-09.

ZAMOS, D.T. et al. Nasopharyngeal conidiobolomycosis in a horse.Journal of the American Veterinary Medical Association, v. 208 , n. 1 , p. $100-101,1996$. 